\title{
VISIBLE AND INVISIBLE WALLS: WORLD TRADE PATTERNS AND THE END OF THE COLD WAR
}

\author{
Peter A.G. van BERGEIJK \\ (Received: 18 July 2013; revision received: 29 April 2014; \\ accepted: 17 August 2014)
}

\begin{abstract}
This paper revisits the empirical trade literature on East-West trade in the early 1990s and provides a replication of the traditional gravity findings of that period with the Baier-Bergstrand version of the model, providing thereby better estimates of the trade hindering impact of the Cold War by including multilateral and world resistance factors and simultaneously considering country fixed effects. Breaking down the Cold War Walls increased world trade by $2.7 \%$ of world GDP. The replication with the Baier-Bergstrand model also reveals that Cold War trade distortions also significantly impacted China's trade with the West.
\end{abstract}

JEL classification indices: F5, F14, N74

Keywords: walls, East-West trade, China, Cold War, globalisation, economic history, replication

A quarter of a century ago, a significant change in the world economic system occurred. During the Cold War, trade on the European continent had been substantially distorted both by (a) the Communist reliance on self-sufficiency, (b) the difficulties imposed by the East's lack of hard and convertible currency, (c) the West imposing embargoes on dual use and technologically advanced goods, and (d) more subtle political barriers to trade. The fall of the Berlin Wall and the Iron Curtain in 1989 did not only ensure that people could travel freely, but also removed the political barriers to trade. The impact of the breakdown of these

Peter A.G. van Bergeijk, Professor of International Economics and Macroeconomics at the International Institute of Social Studies of Erasmus University. E-mail: bergeijk@iss.nl 
"Cold War Walls" went far beyond the breakdown of the visible wall between the peoples of Eastern and Western Europe. Arguably, the invisible political and institutional differences that constituted invisible barriers to trade may have mattered the most. Indeed, for a number of years, double-digit growth rates characterised the trade flows from Eastern to Western Europe and from Western to Eastern Europe (Figure 1; Agudelo - Davidson 2006; Afman - Maurel 2010).

The break-up of a number of formerly communist nations (the Soviet Union, Yugoslavia, and Czechoslovakia) into several new countries ${ }^{1}$ and the unification ${ }^{2}$ of the BRD (West Germany) and the DDR (East Germany) into the Germany that we know today complicate the analysis, but still, it is clear that the trade between Eastern and Western Europe increased many-fold and did so at a pace that was much faster than foreseen by even optimistic observers in 1989. Interestingly, trade economists were keen to point out the impact of the end of the Cold War for the European continent, but were less sharp regarding the impact in the Asian theatre where Cold War Walls were also crumbling.

25 years later, under the spell of the Crimean crisis, this article takes a fresh look at the empirical trade literature on East-West trade in the early 1990s in order to find out whether trade economists who, on the one hand, competently dealt with the consequences of the end of the political and diplomatic trade barriers that were associated with the Berlin Wall and the Iron Curtain, may, on the other hand, have overlooked the consequences of the crumbling of a similar but less visible barrier to trade, namely the external trade relationships of China. China's external trade was also characterised by double-digit growth rates. An example is SinoSouth Korean trade that was negligible in the $1980 \mathrm{~s}$, but showed very large gains in the 1990s and 2000s (Chung 2009; see also Kaplinsky - Messner 2008 on the slow and broad based integration of China in the global political and economic system; Bussière - Schnatz 2006 for an empirical analysis of the advent of China; and Flores-Macias - Kreps 2013 for an analysis of Chinese trade and political relations across Latin America and Africa). For the lack of a better metaphor, I will refer to this invisible wall as the Chinese Wall. As will become clear, autarky, lack of convertible currency, formal embargoes, and more subtle diplomatic barriers to trade - as in the case of the Berlin Wall and the Iron Curtain - significantly suppressed China's foreign trade.

I investigate the issue of the impact of walls deploying two different methodologies. First, I will use the framework of the earliest econometric investigation of the potential trade impact of the fall of the Berlin Wall and the Iron Curtain

See Fidrmuc - Fidrmuc (2003) on economic disintegration.

See Nitch - Wolf (2013) for a gravity analysis of the German unification and the persistent effects of the Berlin Wall even after its demolition. 


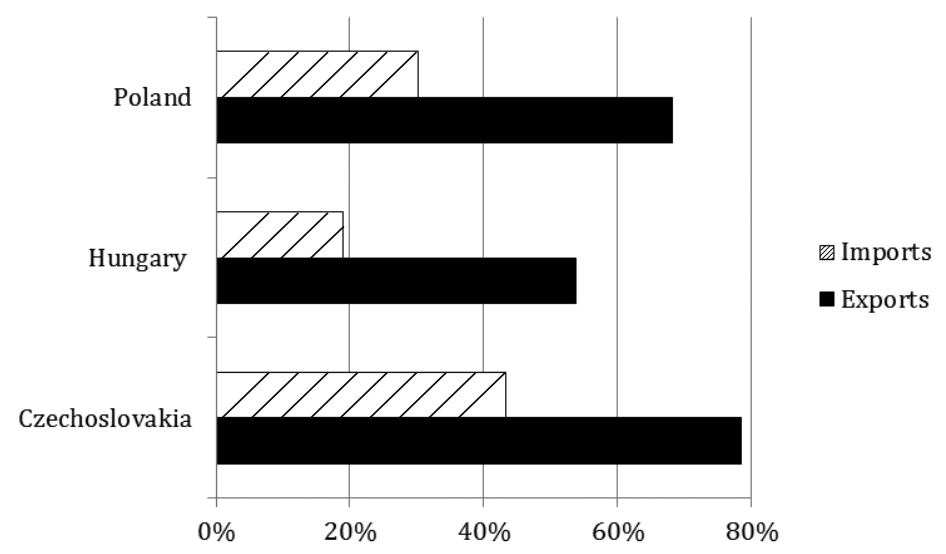

Figure 1.Total real growth of trade with OECD (1990-92)

Source: OECD (1993), Table 25, p. 122

(van Bergeijk - Oldersma 1990). ${ }^{3}$ Second, I will use the modern reformulation of the gravity equation that comprises multilateral resistance terms as introduced by Anderson - van Wincoop (2003). More specifically, I will use the Baier - Bergstrand $(2009,2010)$ version of the gravity model and include multilateral and world resistance, detect country and region-specific effects that may be subdued in fixed effects gravity models and provide comparative statistics regarding the disappearance of walls consistent with general equilibrium.

This article moves beyond the stage of simple replication, although replication in itself is already useful since better estimates for Gross Domestic Product exist than those that were available in early 1990 and because the estimation technology has greatly improved, in particular due to the methodological innovations following Anderson - van Wincoop (2003). The original contributions of this paper are threefold. First, this article provides a better and more exact estimation of the trade hindering impact of the Cold War Walls due to both the inclusion of multilateral and world resistance factors and the simultaneous consideration of country fixed effects. Second, this article provides simulations of the economic impact of the removal of Cold War Walls. Third, by doing so, the article uncovers and illustrates some of the basic economics of walls in an empirically relevant context.

The article originally appeared in Dutch as Normalisering van het OostWest handelsverkeer. Economisch Statistische Berichten (ESB), 12 December 1989, 74 (Nr. 3737), pp. 1244-1246. 
The remainder of this article is organised as follows. The next section sets out the groundwork for the methodology and the analysis as it reviews the literature on the impact of the breakdown of the Berlin Wall and the Iron Curtain in the early 1990s. As will become clear, the empirical analyses in the 1990s relied heavily on the so-called gravity analysis. I discuss this model, pay attention to some of the recent applications that deal with the impact of invisible trade barriers such as trust and cultural and institutional factors, and examine methodological innovations. Section 2 sets out the empirical approach and deals with data issues (the latter is especially relevant because the communist economies reported statistical aggregates that differed substantially from the concepts that are used in market economies, such as GDP). Section 3 discusses the econometric results of two versions of the gravity equation that are used to investigate the impact of the Cold War Walls. Section 4 uses the gravity parameter estimates for 1988 in simulations that investigate the impact of both the Berlin Wall and the Iron Curtain, and the "invisible" Chinese Wall. Section 5 summarises the main findings and draws a number of methodological lessons that are relevant for research on the economics of walls and policy.

\section{ON GRAVITY}

It was recognised early on that walls typically distort economic exchanges between locations on either side of the wall and that the analysis of any wall thus essentially has to deal with the geography of economic activity. A useful research tool to describe the geographical patterns of bilateral economic exchange and interaction between economic agents is the gravity model.

The gravity model is most often applied to international bilateral trade and investment, but many more applications exist (see van Bergeijk - Brakman 2010 for the state-of-the-art). The gravity model derives its name from its similarity with the Newtonian Law of Gravity as the simple and very intuitive idea of this model is that economic masses interact more strongly if they are large and/or in close range of one another. Economic gravity rests on an elementary concept: bilateral interaction increases in the economic masses of the trade partners and decreases in the distance between the trade partners. This simple idea has now been used for six decades to analyse bilateral trade flows with remarkably good statistical performance and robust results regarding the main drivers of and obstacles to international trade. Importantly, the gravity approach fitted the research questions of one of the biggest natural experiments of the 1990s quite well. Breuss - Egger (1999: 82) argue that "the opening up of Eastern Europe in 1989 revealed a new field of application for the gravity approach". Also, in view of the gravity model's 
excellent empirical and statistical performance, it was no surprise that this model became the most important tool to analyse the impact of the fall of the Berlin Wall and the Iron Curtain.

\subsection{Literature of the $1990 \mathrm{~s}$}

The most striking reaction amongst Western policy makers to the collapse of Communism in 1989 was a common disbelief in the trade potential of Eastern Europe. ${ }^{4}$ The popular perception was that the quality of products from Eastern Europe was simply insufficient to meet international competition. This perception was built both on the a-typical pattern of international specialisation that existed within the CMEA and on the low volume of trade between East and West (and vice versa). Also, the widespread inefficiency of production was used to support the argument that exports from Eastern Europe could not be competitive on OECD markets. ${ }^{5}$

Still, the applied trade research at that time revealed that major shifts in trade patterns were eminent, essentially because researchers recognised the validity of the key concept of comparative advantage, that is, that international trade is also beneficial for countries that are inefficient in the production of all goods (these countries have absolute disadvantage in all goods). These countries can specialise in the good(s) or industry/industries in which they are relatively least inefficient and this provides opportunities for mutual beneficial trade. Breaking down Cold War Walls enabled the start of this process, although obviously more would be needed in order to make real progress. So while it was a priori unknown how long it would take before the trade benefits of the breakdown of the Berlin Wall and the Iron Curtain would emerge, it was beyond doubt that trade potential increased due to the removal of these manmade barriers to trade.

Most researchers (e.g., Havrylyshyn - Pritchett 1991; Wang - Winters 1991; Döhrn - Milton 1992; Ezran et al. 1992; Hamilton - Winters 1992) estimated the gravity model for a large number of countries and used the parameters and the observed distances, GDPs, and populations to calculate the "normal" trade levels for each of the CMEA countries. Next, conclusions were drawn from the comparison of the actually observed trade flows and the "normal" or predicted trade

$4 \quad$ Many policy makers thus opted for unrealistic plans to supply Eastern European countries with enormous capital injections (van Bergeijk - Lensink 1993).

In those years, it was often asked what kind of products the Eastern European countries would be exporting. It took some time before the convincing answer was found: "non-traditional exports". 
flows. In particular, the studies predicted that a turnaround would occur in the geographical pattern of trade: the share of Northern Europe in the trade of Eastern Europe would increase from $25 \%-30 \%$ to $70 \%-75 \%$. With hindsight, these studies were very helpful for understanding and predicting the enormous trade reorientation due to the fall of the Berlin Wall (as part of the Iron Curtain's collapse). One drawback, however, is that these studies (while rightly indicating the shifts in the relative geographical patterns, especially in Europe) did not investigate (or report) the increase in global and regional trade potential.

The procedure in van Bergeijk - Oldersma (1990) differs from the basic methodology in the other studies of the 1990s, because it directly estimated the impact of the Wall by means of a dummy variable rather than by deriving the impact from a comparison between actual and predicted trade flows as was done by most authors. Instead, the estimated gravity model was used to simulate post-Cold War trade patterns, avoiding many measurement and interpretation problems and at the same time arriving at indications of changes of trade potentials around the globe.

\subsection{Literature on the "new" trade barriers}

It is relevant to review some of the new avenues in the empirical literature because this line of research substantiates the idea that "unseen walls" exist and that these invisible (or at least not directly observable) barriers to trade can exert a strong impact in the real economy. Of course, these manners of barriers have always existed, but they remained unobserved because transportation costs were exerting a much stronger impact on trade. The substantial reductions in the costs of transportation and communication (travel and exchange of ideas) in recent decades have removed that veil. Indeed, although the "death of distance" has been claimed many times in the popular press on globalisation, a persistent finding in the application of gravity models is that distance continues to matter and that the importance of this factor increased in recent decades (see the meta-analysis by Disdier - Head 2008). Recent studies therefore focus on other forms of distance effects related to indirectly observed differences in trust, value systems (cultural norms), and institutional quality, often uncovering very significant impacts on trade flows (Table 1). The message conveyed by Table 1 is that invisible barriers clearly matter.

A second, more recent strand of literature is relevant for the issue of invisible, politically inspired barriers to trade deals with the impact of economic diplomacy (negative and positive political interactions between countries). This literature was pioneered in the 1980s and 1990s, and at that time it studied so-called events 
Table 1

Impact of a one standard deviation change in intangible trade barriers on exports ( $\%$ change)

\begin{tabular}{l|c}
\hline Increase in trust & $24-38^{\mathrm{a}, \mathrm{b}, \mathrm{c}}$ \\
\hline Decrease in cultural diversity & $-14-8^{\mathrm{a}, \mathrm{d}, \mathrm{e}}$ \\
\hline Increase in institutional quality & $22-45^{\mathrm{d}}$ \\
\hline
\end{tabular}

Source: Adapted from van den Berg et al. (2008), Table 3.6, pp. 37-38.

Notes: ${ }^{\mathrm{a}}$ Dekker et al. (2006), ${ }^{\mathrm{b}}$ den Butter - Mosch (2003), ${ }^{\mathrm{c}}$ Guiso et al. (2004), ${ }^{\mathrm{d}}$ Linders et al. (2005),

${ }^{\mathrm{e}}$ Lankhuizen et al. (2008).

data and intensively used gravity models (see van Bergeijk 1994 and 2009, Chapter 2 for a detailed review of that literature). In the mid-2000s, the topic returned on the research agenda again, but was more focused on concrete structures (such as the network of embassies and consulates) and activities (such as state visits). Again, most analyses used gravity as a basic concept. Moons - van Bergeijk (2013) provide a meta-analysis of 24 studies covering both the early and the recent studies reaffirming that diplomacy exerts a strong impact on trade.

\section{EMPIRICAL DESIGN AND DATA ISSUES}

The empirical design firstly deploys the basic equation of van Bergeijk - Oldersma (1990), Wang - Winters (1991), and Hamilton - Winters (1992), who all relate exports to GDPs, populations, and distance. Using this traditional form, I first estimate cross country a gravity model for the global pattern of bilateral trade from 1988 data in which politically induced distortions in the bilateral Chinese and East-West trade flows are modelled by dummy variables:

$$
\ln E_{i j}=\mathrm{c}+\alpha \ln Y_{i}+\beta \ln Y_{j}+\gamma \ln D_{i j}+\delta \ln N_{i}+\zeta \ln N_{j}+\eta W_{i j}++\varepsilon_{i j}
$$

where $E_{i j}=$ exports of country $i$ to country $j$

$Y_{x}=$ GDP of country $x$

$N_{x}=$ population of country $x$

$D_{i j}=$ distance between capitals of country $i$ and $j$

$W_{i j}=$ dummy variable for bilateral trade flow between country $i$ and $j$ that crosses wall

$\varepsilon=$ error term. 
Secondly, I estimate the Baier and Bergstrand (2010) gravity equation treating the Wall as a trade cost factor: ${ }^{6}$

$$
\begin{gathered}
=c-(1-\sigma) \rho \ln D_{i j}-\lambda(1-\sigma) W_{i j}+(1-\sigma) \rho m w r D_{i j}+\lambda(1-\sigma) m w r W_{i j}+\varepsilon_{i j} \\
\text { where } m w r D_{i j}=\frac{1}{N}\left(\sum_{j=1}^{N} \ln D_{i j}\right)+\frac{1}{N}\left(\sum_{i=1}^{N} \ln D_{i j}\right)-\frac{1}{N^{2}}\left(\sum_{i=1}^{N} \sum_{i=1}^{N} \ln D_{i j}\right) \text { and } \\
\qquad m w r W_{i j}=\frac{1}{N}\left(\sum_{j=1}^{N} W_{i j}\right)+\frac{1}{N}\left(\sum_{i=1}^{N} W_{i j}\right)-\frac{1}{N^{2}}\left(\sum_{i=1}^{N} \sum_{i=1}^{N} W_{i j}\right) .
\end{gathered}
$$

I add country fixed effects to equation 2 in order to capture country (exporter or importer) specific effects, including population size, similarity of languages, landlocked or island status, etc. Many explanatory variables could be added to this equation (as is common practice in most traditional gravity analyses). I am, however, interested in a simulation and only need a reasonably good approximation for the key determinants of the network of world trade. For that reason, I want to focus on geography (distance) and on the time variant variables GDP (equations 1 and 2) and population (equation 1), and incorporate fixed effects to deal with other factors. Being an island, for example, will not change during the simulations and can thus be ignored in the simulations. Importantly, one of the most commonly applied explanatory variables (adjacency or a common border between nations) is problematic in my investigation because this would cause problems with the German unification (Poland, for example, became Germany's neighbour in addition to the disappearance of the Berlin Wall and the Iron Curtain, including the splitting up of countries such as the Soviet Union so that it would be difficult to logically distinguish the contributions of adjacency and wall). ${ }^{7}$

6 I follow Baier - Bergstrand (2010: 104-105) and calculate the multilateral and world resistance factors using equal weights $(1 / N)$ rather than GDP-share weights. Baier - Bergstrand (2010: 109-114) provide extensive Monte Carlo analyses in support of this approximation, finding very small bias (less than $0.5 \%$ ).

7 The German unification and the break-up of the USSR in 1991 and the Socialist Federal Republic of Yugoslavia as well as the dissolution of Czechoslovakia in 1993 are factors that make a panel analysis or a before-after analysis impossible, because domestic trade changes into international trade and vice versa. 


\subsection{Country coverage}

The country coverage is almost the same selection as the one that was originally made in 1990 by van Bergeijk and Oldersma and is guided by the considerations to cover the most important trading nations, all continents, different economic systems and levels of development. With hindsight, that selection was rather lucky since almost all G20 countries are on board, in particular the country group known nowadays as the BRIICS (Brazil, Russia, India, Indonesia, China and South Africa).

The country sample covers Algeria, Austria, Australia, Belgium, Brazil, BRD, Bulgaria, Canada, China, Czechoslovakia, DDR, Denmark, Egypt, Finland, France, Greece, Hungary, India, Indonesia, Ireland, Italy, Japan, Malaysia, Mexico, the Netherlands, New Zealand, Nigeria, Norway, Pakistan, Poland, Portugal, Romania, Saudi Arabia, Singapore, South Africa, South Korea, Spain, Sweden, Switzerland, Taiwan, Thailand, Turkey, UK, USA, USSR/Russia, Venezuela, and Yugoslavia.

\subsection{Trade}

Clearly, a dataset that deals with history needs to take into account that countries have disappeared since the 1990s. In addition, since I want to study the invisible Chinese Wall, I want to include Taiwan for obvious reasons. These requirements imply that I cannot use data sources that only use countries that are identified in the last ISO country list (as, for example, is the case with the Head and Mayer dataset that is available from CEPII) or that I have to be politically correct and thus exclude Taiwan (such as trade data sets provided by the international organisations). For these reasons, I use Gleditsch's comprehensive trade data set, although it does not provide data on Hong Kong. ${ }^{8}$ The trade data relate to 1988 exports. Due to the logarithmic transformation, the model cannot handle zero flows (no bilateral trade) and therefore an arbitrary linear transformation was performed adding the threshold value ( $\$ 0.5$ million) to all export flows by van Bergeijk Oldersma (1990). In contrast, I exclude the zero flows because the problem is very limited in my dataset ( 65 flows or 3\%) but, more importantly, because more than half of the zero trade cases involve South Africa due to far reaching official sanctions and consumer boycotts against apartheid, and given the very specific reason for these zero flows, I do not want to consider these in the estimations. 


\subsection{GDP and population}

I rely on Maddison's historical series for population in 1000s and GDP per capita (in millions of 1990 international Geary-Khamis dollars). Van Bergeijk - Oldersma (1990) use PPP data from the International Comparisons Project, but I prefer Maddison's data for three reasons. ${ }^{9}$ First, Maddison's benchmark year is closer to the year of observation for the data (1990 vs. 1985 or 1996 for the ICP). Second, both my models relate to GDP and international trade, and thus are best served by a method that does not correct for differences in purchasing power due to different prices for non-traded goods as is done in the ICP. Third, ICP uses procedures to ensure consistency of levels at benchmark years and growth rates between benchmark years. I am not interested in growth rates of GDP, but in GDP levels at a specific point in time that is close to Maddison's benchmark. Hence the choice for the data set of Angus Maddison's Statistics on World Population, GDP and Per Capita GDP, 1-2008 AD. This source is also known as "Maddison's historical series" and is available from the website of the Groningen Growth and Development Centre (www.ggdc.net). Although this dataset provides data for communist states and their derivatives and successor states in case of the collapse of a nation, Maddison does not provide the data for DDR and BRD, but simply seems to have aggregated them into one number for "Germany". Luckily, his 1995 study (pp. 130-132) provides details on his treatment of the two Germanies, so that I can reconstruct the data for BRD and DDR in 1988.

\subsection{Distance}

I follow van Bergeijk - Oldersma (1990) and measure distance as the crow flies using basic geometrics. Distances are calculated from the degrees of longitude and latitude of the capital cities of the trade partners in 1988. Assume the Earth to be a perfect sphere with a circumference of 40,000 kilometres. The coordinates of a point on the unit sphere are

$$
\begin{aligned}
& x=\sin \theta \times \cos \varphi, \\
& y=\sin \theta \times \sin \varphi \text { and } \\
& z=\cos \theta,
\end{aligned}
$$

9 The choice for Maddison's data rather than the ICP data that were used originally in van Bergeijk - Oldersma (1990) also reflects that the developments of countries that no longer exist are not reported in recent vintages of the Penn World Tables. 
where $\theta$ is the normalised latitude $0 \leq \theta \leq \pi$ and $\varphi$ is the normalised longitude $0 \leq \varphi \leq 2 \pi$. The angle $\alpha$ between the vectors $a=[x, y, z]$ and $a^{\prime}=\left[x, y, z^{\prime}\right]$ can be obtained from $\cos \alpha=a \times a$ ' and $\alpha<\pi$. The shortest distance between the two points over the surface of the globe is roughly $20,000 \alpha / \pi$.

\subsection{Walls}

My walls are not made of bricks and mortar, but are dummy variables that assume the value 1 if countries are on opposite sides of the Wall and 0 if they are on the same side of the Wall. I let the data decide about the strength of the Wall: the estimated coefficients for this dummy provide an indication of both the statistical significance and the economic importance of the Wall.

\section{ECONOMETRIC RESULTS}

For comparison, the results of van Bergeijk - Oldersma (1990) are reported in the first column of Table 2. The econometric results for a similar traditional gravity equation are reported in the second column of Table 2; the Baier-Bergstrand gravity model is reported in columns 4 and 5 . In column 6 , I add dummy variables for colonial ties and common language and their respective world and multilateral resistance terms in the same way that I added the wall dummies. As pointed out by one of the referees, the two bilateral variables in the model are distance and the "Wall" dummy, which means that everything not captured by distance could influence the estimated wall parameters. Column 6 thus provides a robustness check by including additional controls that are clearly not elements of Cold War "Walls". ${ }^{10}$

Focussing on the traditional model first (columns 2 and 3), we can observe that the replication of Van Bergeijk - Oldersma (column 2) is quite close for another year (1988 versus 1985) with different data sources and a different sample of countries. ${ }^{11}$ About two-thirds of the variance are explained and the coefficients are of similar size as reported by van Bergeijk - Oldersma and highly significant.

10 Data sources are Mayer - Zignago (2011) for (ex-)colonial ties and Melitz - Toubal (2012) for common languages.

11 I had to leave Iceland out because Maddison does not provide data on its GDP and Hong Kong is integrated in the Chinese trade statistics in the 1988 trade data base that I use and for that reason drops out. 
Table 2

OLS estimates for bilateral trade flows countries (49 countries in 1985 and 48 countries in 1988)

\begin{tabular}{|c|c|c|c|c|c|c|}
\hline \multirow{3}{*}{ Based on data for } & $\begin{array}{c}\text { van } \\
\text { Bergeijk - } \\
\text { Oldersma }\end{array}$ & \multicolumn{2}{|c|}{$\begin{array}{l}\text { Replication } \\
\text { (present study) }\end{array}$} & \multicolumn{3}{|c|}{ Baier-Bergstrand gravity model } \\
\hline & (1) & (2) & (3) & (4) & (5) & (6) \\
\hline & 1985 & 1988 & 1988 & 1988 & 1988 & 1988 \\
\hline $\begin{array}{l}\text { Dependent } \\
\text { variable }\end{array}$ & $\ln E_{i j}$ & $\ln E_{i j}$ & $\ln E_{i j}$ & $\ln \left(\frac{E_{i j}}{Y_{i} Y_{j}}\right)$ & $\ln \left(\frac{E_{i j}}{Y_{i} Y_{j}}\right)$ & $\ln \left(\frac{E_{i j}}{Y_{i} Y_{j}}\right)$ \\
\hline GNP exporter & $\begin{array}{c}1.8 \\
(36.9)\end{array}$ & $\begin{array}{c}1.6 \\
(36.0)\end{array}$ & $\begin{array}{c}1.6 \\
(35.9)\end{array}$ & & & \\
\hline GNP importer & $\begin{array}{c}1.4 \\
(28.7)\end{array}$ & $\begin{array}{c}1.4 \\
(30.9)\end{array}$ & $\begin{array}{c}1.4 \\
(30.8)\end{array}$ & & & \\
\hline $\begin{array}{l}\text { Population } \\
\text { exporter }\end{array}$ & $\begin{array}{c}-1.0 \\
(-23.5)\end{array}$ & $\begin{array}{c}-0.9 \\
(-22.7)\end{array}$ & $\begin{array}{c}-0.8 \\
(-22.1)\end{array}$ & & & \\
\hline $\begin{array}{l}\text { Population } \\
\text { importer }\end{array}$ & $\begin{array}{c}-0.6 \\
(-14.4)\end{array}$ & $\begin{array}{c}-0.6 \\
(-16.7)\end{array}$ & $\begin{array}{c}-0.6 \\
(-16.3)\end{array}$ & & & \\
\hline Distance & $\begin{array}{c}-1.0 \\
(-30.6)\end{array}$ & $\begin{array}{c}-0.9 \\
(-27.3)\end{array}$ & $\begin{array}{c}-0.9 \\
(-27.3)\end{array}$ & $\begin{array}{c}-1.0 \\
(-26.0)\end{array}$ & $\begin{array}{c}-1.0 \\
(-16.7)\end{array}$ & $\begin{array}{c}-1.0 \\
(-25.3)\end{array}$ \\
\hline $\begin{array}{l}\text { Common lan- } \\
\text { guage }\end{array}$ & & & & & & $\begin{array}{c}0.3 \\
(2.2) \\
\end{array}$ \\
\hline Colonial history & & & & & & $\begin{array}{c}0.6 \\
(2.6) \\
\end{array}$ \\
\hline $\begin{array}{l}\text { Berlin Wall and } \\
\text { Iron Curtain }\end{array}$ & $\begin{array}{c}-2.1 \\
(-29.8) \\
\end{array}$ & $\begin{array}{c}-1.3 \\
(-19.2) \\
\end{array}$ & $\begin{array}{c}-1.3 \\
(-19.2) \\
\end{array}$ & $\begin{array}{c}-1.7 \\
(-20.0) \\
\end{array}$ & $\begin{array}{c}-1.7 \\
(-19.5) \\
\end{array}$ & $\begin{array}{c}-1.7 \\
(-19.4) \\
\end{array}$ \\
\hline Chinese Wall & & & $\begin{array}{c}-0.2 \\
(-0.9) \\
\end{array}$ & & $\begin{array}{c}-0.5 \\
(-1.8) \\
\end{array}$ & $\begin{array}{l}-0.5 \\
(-1.7) \\
\end{array}$ \\
\hline Constant & $\begin{array}{c}-3.8 \\
(-18.7)\end{array}$ & $\begin{array}{c}-9.0 \\
(-17.1)\end{array}$ & $\begin{array}{l}-9.1 \\
(-17)\end{array}$ & $\begin{array}{c}\text { Fixed } \\
\text { effects } \\
\text { included }\end{array}$ & & \\
\hline Adjusted $R^{2}$ & 0.65 & 0.64 & 0.64 & 0.72 & 0.72 & 0.72 \\
\hline
\end{tabular}

Note: $t$-values in brackets.

In column 3, I add the Chinese Wall dummy, but that turns out to be completely insignificant.

Next, we turn to the Baier-Bergstrand model in columns 4 to 6 . Note, that the reported coefficient for distance now is $-(1-\sigma) \rho$ so that it considers the relative distance effect (that is, vis-à-vis multilateral and world distance) and has been estimated under the restriction that $\ln D_{i j}$ and $m w r D_{i j}$ have identical effects with opposite signs. Likewise, the reported coefficient for a wall is $-\lambda(1-\sigma)$ and has 
been estimated under the same restriction. Similarly to the traditional gravity model, the Baier-Bergstrand gravity model finds highly significant coefficients for distance and the Berlin Wall and Iron Curtain, but in contrast to the traditional approach also a significant effect of the Chinese Wall (the significance level is modest at $92 \%$ but still sufficient). So while the conclusion of the Van Bergeijk - Oldersma replication suggests that the invisible Chinese Wall can and perhaps should be ignored, the Baier-Bergstrand model that considers multilateral and world aspects of both distance and of the walls shows that the invisible Chinese Wall is a significant barrier to trade. Column 6 reports a robustness check that also includes dummy variables and multilateral and world resistance terms for common language and (ex-)colonial ties. The robustness check supports the earlier findings.

\section{SIMULATION RESULTS}

The next step is to calculate the comparative statics multipliers as $\frac{E_{i j}^{*}}{E_{i j}}=\frac{1}{e^{-\lambda\left(1-D f\left(m w r W_{j}-1\right)\right.}}$ for each Cold War Wall and use these multipliers to predict each bilateral trade flow, that is, the level that would result in the absence of the wall. The simulations cover direct and indirect trade effects (for example, the removal of a wall does not only stimulate trade between the previously opposing sides of the wall, but may also make some previous suppliers less attractive). The simulations do not include dynamic effects (for example on long-term growth). The simulation results are reported in Table 3.

Table 3

Simulation of the impact of Cold War Walls in 1988 (trade increase in percent of regional GDP)

\begin{tabular}{lccc}
\hline & Berlin Wall & Chinese Wall & Cold War Walls \\
\hline Africa & 1.0 & 0.0 & 1.0 \\
Asia, excluding China & 1.6 & 0.2 & 1.8 \\
China & 0.1 & 0.6 & 0.7 \\
Australia, New Zealand & 2.2 & 0.2 & 2.4 \\
Eastern Europe and USSR & 28.1 & 0.0 & 27.7 \\
Latin America & 0.7 & 0.0 & 0.7 \\
Middle East & 1.3 & 0.1 & 1.3 \\
North America & 1.0 & 0.1 & 1.1 \\
West Europe & 4.3 & 0.1 & 4.4 \\
World & 2.6 & 0.1 & 2.7 \\
\hline
\end{tabular}




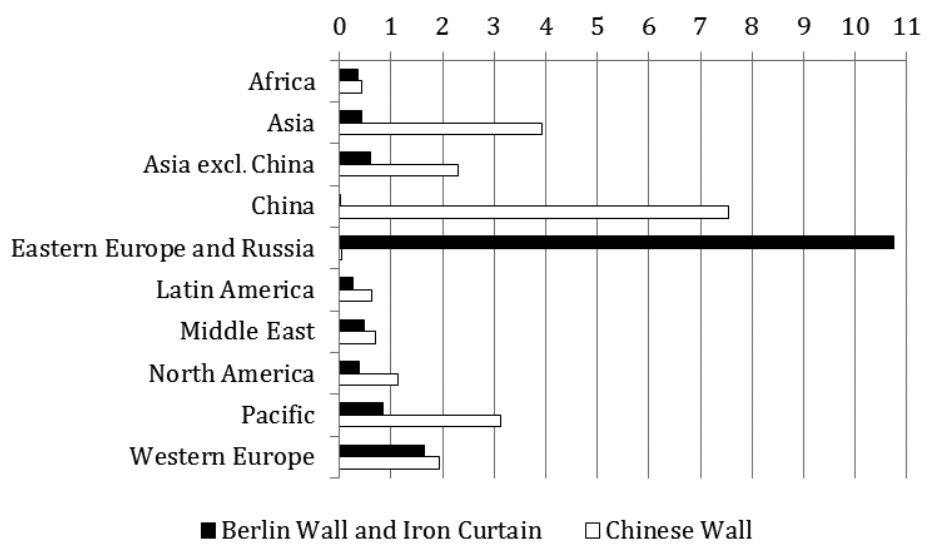

Figure 2. Ratio of regional to world-wide impact (trade increase in percent of GDP)

The results confirm the importance of the Berlin Wall and the Iron Curtain as their statistical significance is also reflected in economic significance, but for the Chinese Wall the impact is generally speaking quite modest. Breaking down the Cold War Walls according to my calculations increased world trade by $2.7 \%$ of world GDP (that is about a third of the increase in global trade openness since 1990). Typically, the trade impact is especially strong at the regional level close to the wall. Figure 2 compares the regional impact to the global impact (using trade potential in per cent of GDP). Interestingly, Figure 2 does not only show relatively strong impacts for the regions that are closest to the respective wall, but also finds relatively strong impacts (that is: above the world average) for the Chinese Wall in Western Europe.

The findings for 1988 do not necessarily mean that the removal of the invisible Chinese Wall, while statistically significant, is economically less significant from a historic perspective. Indeed, it is probable that the regional conditions in this particular case in 1989 were such that trade would be low both with and without walls. In other words, walls cannot distort economic non-activity. An indication, however, of the potential impact of the "invisible Chinese Wall" is that, as illustrated in Figure 2, its relative influence in terms of percentage trade reduction was, comparatively speaking, strong in developed but far away markets in Western Europe. This suggests that the "invisible Chinese Wall" could have started to bite once development in Asia took off. 


\section{DISCUSSION AND CONCLUSIONS}

The results in the previous section should not be seen as accurate predictions (Breuss - Egger 1999), but rather as a serious attempt to uncover the size of the potential impact of a wall that played a major role in recent history. We know from observation that the fall of the Berlin Wall and the Iron Curtain led to an enormous surge in intra-European trade. This observation and the fact that this trade potential was ex ante indicated by a number of gravity analyses in the 1990s motivated a revisit of the empirical trade literature on East-West trade in order to find out if trade economists who, on the one hand, competently dealt with the consequences of political and diplomatic trade barriers that were associated with the very visible Berlin Wall (and the Iron Curtain), may, on the other hand, have overlooked the consequences of invisible - and more gradual - reductions of similar barriers to trade, in particular in the external trade relationships of China. In view of the findings in this paper, the signals that important changes in China's trade were statistically strong, but the short- to medium-term economic implications were weak at most.

The empirical analysis of the world trade system just before the end of the Cold War provides some useful numerical illustrations of general patterns regarding the economic impact of walls. First, walls are not mirrors as illustrated by the different consequences of the Berlin Wall and the Iron Curtain for Western and Eastern Europe. The economics of walls thus should consider the possibility of asymmetries, in particular because the costs of walls and the benefits of their removal can be distributed quite unevenly between the two sides of the wall. Second, the two simulations clarify that the impact of walls depends on local conditions on both sides of the wall, but also on the opportunities that exist for economic interaction with and between entities in wall-free locations. Third, although the impact of walls is obviously the strongest the closest one is to the wall, their impact beyond the local level will often be not negligible as shown by the impact of the Berlin Wall and the Iron Curtain in Australia and New Zealand.

New walls in Europe - even invisible walls - are still much more difficult to conceive than before 1961 when the Berlin Wall was erected, but at the same time one is aware that in the present geopolitical context, a political conflict could recreate significant look-alikes of the Cold War Walls. This article illustrates the important economic costs that would occur in such a scenario. 


\section{REFERENCES}

Afman, E.R. - Maurel, M. (2010): Diplomatic Relations and Trade Reorientation in Transition Countries. In: Bergeijk, P.A.G. van - Brakman, S. (eds): The Gravity Model in International Trade: Advances and Applications. Cambridge, MA: Cambridge University Press, pp. 278-295.

Agudelo, D. - Davidson, L.S. (2006): The Gravity of Globalization. Research in Global Strategic Management, 12: 79-103.

Anderson, J.E. - van Wincoop, E. (2003): Gravity with Gravitas: A Solution to the Border Puzzle. American Economic Review, 93(1): 170-192.

Baier, S.L. - Bergstrand, J.H. (2009): Bonus vetus OLS: A Simple Method for Approximating International Trade-Cost Effects Using the Gravity Equation. Journal of International Economics, 77(1): 77-85.

Baier, S.L. - Bergstrand, J.H. (2010): Approximating General Equilibrium Impacts of Trade Liberalizations Using the Gravity Equation: Applications to NAFTA and the European Economic Area. In: van Bergeijk, P.A.G. - Brakman, S. (eds): The Gravity Equation in International Trade. Cambridge, MA: Cambridge University Press, pp. 88-134.

Berg, M. van den - Nooij, M. de - Garretsen, H. - de Groot, H.L.F. (2008): MKBA buitenlandinstrumentarium (Cost-Benefit Analysis of Trade Policy Instruments). SEO Report, 2008-64. SEO Economic Research, Amsterdam.

Bergeijk, P.A.G. van (1994): Economic Diplomacy, Trade and Commercial Policy: Positive and Negative Sanctions in a New World Order. Cheltenham, UK: Edward Elgar.

Bergeijk, P.A.G. van (2009): Economic Diplomacy and the Geography of International Trade. Cheltenham, UK: Edward Elgar.

Bergeijk, P.A.G. van - Brakman, S. (2010): The Comeback of the Gravity Model. In: Bergeijk, P.A.G. van - Brakman, S. (eds): The Gravity Equation in International Trade. Cambridge MA: Cambridge University Press, pp. 1-26.

Bergeijk, P.A.G. van - Lensink, B.W. (1993): Trade, Capital and the Transition in Central Europe. Applied Economics, 25: 891-903.

Bergeijk, P.A.G. van - Oldersma, H. (1990): Détente, Market-Oriented Reform and German Unification. Potential Consequences for the World Trade System. Kyklos, 43(4): 599-609.

Breuss, F. - Egger, P. (1999): How Reliable are Estimations of East-West Trade Potentials Based on Cross-Section Gravity. Empirica, 26: 81-94.

Bussière, M. - Fidrmuc, J. - Schnatz, B. (2005): Trade Integration of Central and Eastern European Countries: Lessons from a Gravity Model. ECB Working Paper, No. 545, Frankfurt.

Bussière, M. - Schnatz, B. (2006): Evaluating China's Integration in World Trade with a Gravity Model Based Benchmark. ECB WorkingPaper, No. 693, Frankfurt.

Butter, F.A.G. den - Mosch, R.H.J. (2003): Trade, Trust and Transaction Costs. Tinbergen Institute Discussion Paper, No. TI.2003-082/3, Amsterdam.

Chung, J.H. (2009): Between Alley and Partner: Korea-China Relations and the United States. New York: Columbia University Press.

Dekker, P. - Ederveen, S. - de Groot, H. - van der Horst, A. - Lejour, A. - Straathof, B. - Vinken, H. - Wennekers, C. (2006): Divers Europe. European Outlook, 4. The Hague: SDU Publishing Company.

Disdier, A.C. - Head, K. (2008): The Puzzling Persistence of the Distance Effect on Bilateral Trade. Review of Economics and Statistics, 90(1): 37-48.

Döhrn, R. - Milton, A.R. (1992): Zur künftigen Einbindung der osteuropaïschen Reformländer in der Weltwirtschaft (On the Integration into the World Economy of the Reforming Countries in Eastern Europe). RWI-Mitteilungen, 43, pp. 19-40. 
Erzan, R. - Holmes, C. - Safadi, R. (1992): How Changes in the CMEA Area May Affect International Trade in Manufactures. World Bank PRIT Working Papers Series, WPS 973, Washington, D.C.

Fidrmuc, J. - Fidrmuc, J. (2003): Disintegration and Trade. Review of International Economics, 11(5): 811-829.

Flores-Macias, G. - Kreps, S.E. (2013): The Foreign Policy Consequences of China's Economic Rise: A Study of China's Commercial Relations with Africa and Latin America, 1992-2006. Journal of Politics, 75(2): 357-371.

Földvári, P. - Leeuwen, B. van - Didenko, D. (2015): Capital Formation and Economic Growth under Central Planning and Transition: A Theoretical and Empirical Analysis, ca. 1920-2008. Acta Oeconomica, 1: 27-50.

Gleditsch, K.S. (2002): Expanded Trade and GDP Data. Journal of Conflict Resolution, 46(5): $712-724$.

Guiso, L. - Sapienza, P. - Zingales, L. (2004): Cultural Biases in Economic Exchange. NBER Working Paper, 11005, Cambridge, MA.

Hamilton, C.B. - Winters, L.A. (1992): Opening up International Trade with Eastern Europe. Economic Policy, 14: 77-116.

Havrylyshyn, O. - Pritchett, L. (1991): European Trade Patterns after the Transition. World Bank PRE Working Papers Series, WPS 748, Washington, D.C.

Kaplinsky, R. - Messner, D. (2008): Introduction: The Impact of Asian Drivers on the Developing World. World Development, 36(2): 197-209.

Lankhuizen, M. - Linders, G.J. - de Groot, H.L.F. (2008): Distance and the Mode of Serving Markets. TI Discussion Paper, Amsterdam.

Linders, G.J. (2006): Intangible Barriers to Trade. PhD Thesis. Amsterdam: Vrije Universiteit.

Maddison, A. (1995): Monitoring the World Economy 1820-1992. Paris: OECD.

Mayer, T. - Zignago, S. (2011): Notes on CEPII's Distances Measures: The GeoDist Database. CEPII Working Papers, No. 2011-25, Paris.

Melitz, J. -1 Toubal, F. (2012): Native Language, Spoken Language, Translation and Trade. CEPII Working Papers, 2012-17, Paris.

Moons, S. - Bergeijk, P.A.G. van (2013): Does Economic Diplomacy Work? A Meta Analysis on the Effect of Economic Diplomacy on International Economic Flows. Paper presented the 7th Colloquium of the Meta Analysis of Economic Research Network (MAER-Net), University of Greenwich.

Nitsch, V. - Wolf, N. (2013): Tear Down This Wall: On the Persistence of Borders in Trade. Canadian Journal of Economics/Revue canadienne d'économique, 46(1): 154-179.

OECD (1993): Economic Outlook 53. Paris.

Wang, Z.K. - Winters, L.A (1991): The Trading Potential of Eastern Europe. CEPR Discussion Paper Series, 610, London. 